\title{
Analysis of Bromodeoxyuridine Incorporation into DNA: Comparison of Gas Chromatographic/Mass Spectrometric, CsCl Gradient Sedimentation, and Specific Radioactivity Methods ${ }^{1}$
}

\author{
Jonathan Maybaum, ${ }^{*, 2,3}$ Matthew G. KotT, ${ }^{*}$ Norma J. JohnSON, $\dagger$ \\ William D. ENSMINGER, † AND PHILIP L. STETSON* \\ Departments of ${ }^{\star}$ Pharmacology and $\dagger$ Internal Medicine, University of Michigan \\ Medical School, Ann Arbor, Michigan 48109-0504
}

Received July 24, 1986

\begin{abstract}
A sensitive new method for the quantitation of 5-bromodeoxyuridine (BrdUrd) incorporated into DNA by $\mathrm{GC} / \mathrm{MS}$ analysis of enzymatically released Thy and bromouracil (BrUra) is presented. The hydrolysis procedure was characterized and found to give uniform results when sample size was 1-10 $\mu \mathrm{g}$ DNA and incubation time for DNA digestion was between $40 \mathrm{~min}$ and $16 \mathrm{~h}$. Samples of DNA containing ${ }^{3} \mathrm{H}$-labeled BrdUrd were analyzed in parallel by the GC/MS technique and by specific radioactivity and buoyant density measurements, in order to compare the three methods. The GC/MS procedure gave values for percentage replacement of Thy by BrUra which were higher than those obtained by specific activity and lower than those obtained by buoyant density. This GC/MS method can detect $1 \%$ replacement in a $1-\mu \mathrm{g}$ DNA sample, equivalent to approximately $10^{5}$ cells or $0.1 \mathrm{mg}$ tissue, and will permit sensitive and quantitative analysis of the presence of this chemotherapeutic agent/radiosensitizer in cellular DNA from biopsy samples of normal or tumor tissue. (c) 1987 Academic Press, Inc.

KEY WORDS: gas chromatography-mass spectrometry; ultracentrifugation; DNA; purines and pyrimidines; cancer chemotherapy.
\end{abstract}

The thymidine analog 5-bromodeoxyuridine (BrdUrd) ${ }^{4}$ has long been recognized for its capacity to become incorporated into DNA and, as one result of such incorporation, to sensitize cells to radiation (1). Several reports have shown that the magnitude of this radiosensitization is proportional to the extent to which BrdUrd replaces dThd in DNA (2-5). In most such studies BrdUrd incorporation has been calculated on the basis

\footnotetext{
${ }^{1}$ Supported in part by Grants CA40260 and CA33825 NCI, NIH, DHHS.

${ }^{2}$ To whom reprint requests should be addressed at the Upjohn Center for Clinical Pharmacology, Room 4302A, The University of Michigan Medical Center, Ann Arbor, MI 48109-0504.

${ }^{3}$ Recipient of a Faculty Development Award from the Pharmaceutical Manufacturer's Association Foundation.

${ }^{4}$ Abbreviations used: BrdUrd, 5-bromodeoxyuridine; BrUra, bromouracil; SDS, sodium dodecyl sulfate.
}

of changes in buoyant density of DNA extracted from treated cells by the use of $\mathrm{CsCl}$ gradient sedimentation. There are a number of serious difficulties associated with this procedure, however. For example, relatively few samples can be processed at a time (depending on the number of available rotors and centrifuges); the formation, fractionation, and analysis of the gradients are time consuming; and such analyses require either large quantities of DNA (enough to be detected by uv absorbance) or radiolabeled DNA, which might not be easily obtained from clinical tissue specimens. Since there has recently been a resurgence of interest in the clinical use of BrdUrd as a radiosensitizer (6), we felt that a more convenient and direct means of measuring BrdUrd incorporation would be a useful tool. In this paper we describe a technique in which DNA is isolated from cells and enzymatically hydrolyzed to 
yield thymine and bromouracil, which are then quantitated by GC/MS analysis. A comparison of results obtained by use of this method versus those found by employing $\mathrm{CsCl}$ gradient analysis and specific radioactivity calculations is presented, showing that the GC/MS technique yields values for the extent of replacement of dThd by BrdUrd which are intermediate between the other two techniques.

\section{MATERIALS AND METHODS}

Cell growth, drug treatment, and DNA preparation. V79 cells were grown as monolayers in $150-\mathrm{cm}^{2}$ tissue culture flasks in $\alpha$-MEM containing $5 \%$ fetal calf serum. L1210 cells were grown as suspension cultures in RPMI 1640 containing $10 \%$ horse serum. Media and sera were purchased from GIBCO. BrdUrd solutions were freshly prepared for each experiment by dissolving BrdUrd powder (Sigma) in $0.1 \mathrm{M} \mathrm{NaOH}$ and diluting a small aliquot of this filter-sterilized stock solution into the medium. Drug concentration in the stock solution was checked by uv absorbance. Radioactive BrdUrd solutions were made by combining stock $\left[{ }^{3} \mathrm{H}\right]$ BrdUrd $\left(6-{ }^{3} \mathrm{H}, 16 \mathrm{Ci} / \mathrm{mmol}\right.$, Moravek Biochem.) with unlabeled BrdUrd to achieve a final specific activity of $188 \mathrm{mCi} / \mathrm{mmol}$. Radiolabeled dThd $\left(2-{ }^{14} \mathrm{C}, 56 \mathrm{mCi} / \mathrm{mmol}\right)$ was also purchased from Moravek. After drug treatment cells were harvested by trypsinization and pelleted, the medium was removed, and $1.0 \mathrm{ml}$ of lysis buffer was added (10 mM Tris- $\mathrm{HCl}, \mathrm{pH} 8.0,1 \mathrm{mM}$ EDTA, $0.6 \%$ SDS). Lysates were sheared with an $18-$ gauge needle and then treated with proteinase $\mathrm{K}$ (Sigma), $50 \mu \mathrm{g} / \mathrm{ml}$, for $2 \mathrm{~h}$ at $37^{\circ} \mathrm{C}$. This material was then extracted twice with chloroform and precipitated with 2 vol of ice-cold $95 \%$ ethanol and a final concentration of $0.1 \mathrm{M} \mathrm{NaCl}$ and kept at $-20^{\circ} \mathrm{C}$. After ethanol precipitation the samples were allowed to warm to room temperature and the DNA was pelleted, air-dried, and dissolved in at least $1.0 \mathrm{ml}$ of $\mathrm{TE}(10 \mathrm{mM}$ Tris $-\mathrm{HCl}$, pH $8.0 ; 1 \mathrm{~mm}$ EDTA). Samples were then treated with DNase-free RNase at a concentration of $0.02 \mathrm{mg} / \mathrm{ml}$ for $2 \mathrm{~h}$ at $37^{\circ} \mathrm{C}$, chloroform extracted once, and ethanol precipitated as before.

DNA hydrolysis. Aliquots of DNA solutions were diluted to a final volume of $250 \mu$ with TM (10 mM Tris- $\mathrm{HCl}$, pH 8.0; $10 \mathrm{mM}$ $\mathrm{MgCl}_{2}$ ) and $50 \mu \mathrm{l}$ of "enzyme mix." Enzyme $\operatorname{mix}$ contains $2 \mathrm{mg} / \mathrm{ml}$ DNase $\mathrm{I}, 4 \mathrm{mg} / \mathrm{ml}$ phosphodiesterase, 70 units $/ \mathrm{ml}$ alkaline phosphatase, and 25 units/ml thymidine phosphorylase in TM (pH 8.0) and is made fresh daily. All enzymes were supplied by Sigma. The hydrolysis reaction was carried out for $1 \mathrm{~h}$ (unless indicated otherwise) at $37^{\circ} \mathrm{C}$ and stopped by adding $100 \mu \mathrm{l}$ of saturated ammonium sulfate. Hydrolysates were stored at $-20^{\circ} \mathrm{C}$ until extraction, derivatization, and analysis by GC/MS, as described previously (7).

Determination of incorporation using $\mathrm{CsCl}$ gradients. Five milliliters of $\mathrm{CsCl}$ solution (at a starting density of 1.712 to $1.726 \mathrm{~g} / \mathrm{ml}$, $25^{\circ} \mathrm{C}$ ) including aliquots of both ${ }^{14} \mathrm{C}$-labeled (control) and ${ }^{3} \mathrm{H}$-labeled (BrdUrd) DNA was placed in a Beckman Ultra-Clear centrifuge tube. Each tube contained no more than $2 \mu \mathrm{g}$ of DNA. An overlay of $6 \mathrm{ml}$ of light mineral oil was added, and the tubes were capped and then centrifuged in a Beckman L8-70M U1tracentrifuge for $45 \mathrm{~h}$ at $36000 \mathrm{rpm}$ at $25^{\circ} \mathrm{C}$ in a type $70.1 \mathrm{Ti}$ rotor. After centrifugation the tubes were individually pierced and consecutive $170-\mu$ l fractions were removed from the bottom using an ISCO Model 184 fractionator. For each tube the density of every odd-numbered fraction was determined by refractometry. To the remaining portion of each fraction $2 \mathrm{ml}$ of distilled water and 15 $\mathrm{ml}$ of Safety-Solve were added and the radioactivity was counted in each fraction. The percentage of total corrected counts was plotted against fraction number and the density of peaks was determined from a linear least-squares fit for the densities along the gradient. GC content of normal DNA was determined using the following equation: density $=1.66+0.098 \mathrm{GC}$ where GC is the percentage of guanine plus cytosine (8). Per- 
TABLE 1

RECOVERY OF $\left[{ }^{3} \mathrm{H}\right]$ BrUTa FROM DNA CONTAINING $\left[{ }^{3} \mathrm{H}\right] \mathrm{BrdUrd}^{a}$

\begin{tabular}{lcccccc}
\hline $\begin{array}{c}\text { BrdUrd } \\
\text { concn. } \\
(\mu \mathrm{M})\end{array}$ & $\begin{array}{c}\text { cpm } \\
\text { injected }\end{array}$ & $\begin{array}{c}\text { cpm } \\
\text { recovered }\end{array}$ & $\begin{array}{c}\text { cpm recovered } \\
\text { as BrUra }\end{array}$ & $\begin{array}{c}\text { \% Recovered } \\
\text { cpm in } \\
\text { BrUra peak }\end{array}$ & $\begin{array}{c}\text { nmol dThd } \\
\text { recovered }\end{array}$ & $\begin{array}{c}\text { \% Replacement of } \\
\text { Thy by BrUra }\end{array}$ \\
\hline 0.11 & 822 & 870 & 827 & 95.1 & 0.48 & 1.4 \\
0.11 & 986 & 773 & 730 & 94.4 & 0.44 & 1.4 \\
0.33 & 4444 & 3636 & 3490 & 95.6 & 0.53 & 5.2 \\
0.33 & 4304 & 3723 & 3566 & 95.8 & 0.55 & 5.1 \\
0.33 & 4364 & 3612 & 3457 & 95.7 & 0.56 & 4.9 \\
1.0 & 9786 & 7002 & 6707 & 95.8 & 0.30 & 15.7 \\
1.0 & 8002 & 7136 & 6858 & 96.1 & 0.44 & 11.5 \\
\hline
\end{tabular}

${ }^{a}$ DNA was extracted from V79 cells grown in the indicated concentration of $\left[{ }^{3} \mathrm{H}\right] \mathrm{BrdU}$ rd (sp act $188 \mathrm{mCi} / \mathrm{mmol}$ ) for $48 \mathrm{~h}$ and then hydrolyzed as described in the text. The hydrolysate was injected onto a reverse-phase HPLC column and $1.1-\mathrm{ml}$ fractions were collected, mixed with an aqueous-compatible scintillation cocktail, and assayed for ${ }^{5} \mathrm{H}$ by liquid scintillation counting. Thymidine content of each sample was determined by use of an external calibration curve and extent of Thy replacement by BrUra was calculated on the basis of ${ }^{3} \mathrm{H}$ recovered as BrUra and recovered dThd, using an experimentally determined ${ }^{3} \mathrm{H}$ counting efficiency of $29 \%$.

centage BrdUrd incorporation was calculated as in Ref. (9), assuming that BrdUrd incorporation causes no significant change in the partial specific volume of DNA.

HPLC analysis. The HPLC system consisted of an Altex 110 pump, a Rheodyne 7120 injector with a $200-\mu 1$ loop, and a Waters 440 uv absorbance detector fixed at $280 \mathrm{~nm}$. DNA hydrolysates were extracted with chloroform before being injected onto a Regis $4.6 \times 250-\mathrm{mm}, 5-\mu \mathrm{m}$ ODS column, using a mobile phase containing $10 \mathrm{~mm}$ $\mathrm{NaOAc}, \mathrm{pH} 5.0,5 \% \mathrm{MeOH}$ at a flow rate of $1.1 \mathrm{ml} / \mathrm{min}$. Under these conditions Thy, BrUra, dThd, and BrdUrd eluted at 8.5, 9.5, 21 , and $29 \mathrm{~min}$, respectively.

\section{RESULTS AND DISCUSSION}

\section{Characterization of DNA Hydrolysis}

In order to determine the efficiency of liberation of thymine and bromouracil from DNA we used HPLC to analyze the hydrolysate of DNA containing either $\left[{ }^{14} \mathrm{C}\right] \mathrm{dTh}$ or $\left[{ }^{3} \mathrm{H}\right] \mathrm{BrdU}$ rd. Table 1 shows that when the incorporated radioactivity was $\left[{ }^{3} \mathrm{H}\right] \mathrm{BrdUrd}$ $85 \%$ of injected radioactivity was recovered in the collected fractions, and at least $95 \%$ of the cpm coeluted with bromouracil, with the remaining cpm eluting at the same time as thymine. The identity of this minor component was not investigated further. In hydrolysates of DNA samples containing $\left[{ }^{14} \mathrm{C}\right] \mathrm{dTh}$ all detectable radioactivity $\mathrm{co}-$ eluted with thymine, accounting for 85.5 $\pm 3.2 \%(\mathrm{SD}, N=3$ ) of injected cpm. We conclude from these data that the hydrolysis conditions used here release both thymine and bromouracil from DNA with high efficiency and with little or no alteration of their chemical identities.

The time course of hydrolysis under these conditions is quite rapid, as shown by the data in Table 2. Since $10 \mu \mathrm{g} \mathrm{L1210} \mathrm{DNA}$ would be expected to contain approximately $9 \mathrm{nmol}$ of Thy + BrUra (assuming 40\% G $+C$ content and an average of $330 \mathrm{Da}$ per monophosphate) the observed amounts of these two bases indicate that hydrolysis is complete after $40 \mathrm{~min}$ of incubation. In other experiments we hydrolyzed replicate samples of 1 or $5 \mu \mathrm{g}$ of the same DNA preparation for $16 \mathrm{~h}$ and observed values for replacement of Thy by BrUra of $32.7 \pm 1.6$ and $34.7 \pm 0.5 \%$, respectively ( $\pm \mathrm{SD}, N=4$ ). The mean of all of the values in Table 2 is 34.2 
TABLE 2

TIME COURSE OF DNA HYDROLYSIS ${ }^{a}$

\begin{tabular}{ccccc}
\hline $\begin{array}{c}\text { Incubation time } \\
(\mathrm{min})\end{array}$ & $\begin{array}{c}\text { nmol BrUra } \\
\text { recovered }\end{array}$ & $\begin{array}{c}\text { nmol Thy } \\
\text { recovered }\end{array}$ & $\begin{array}{c}\text { Total nmol } \\
\text { recovered }\end{array}$ & $\begin{array}{c}\text { \% Replacement of } \\
\text { Thy by BrUra }\end{array}$ \\
\hline \multirow{2}{*}{20} & 2.41 & 4.60 & 7.01 & 34.4 \\
& 2.75 & 5.33 & 8.08 & 34.0 \\
40 & 2.95 & 5.60 & 8.55 & 34.5 \\
& 3.28 & 6.20 & 9.48 & 34.6 \\
60 & 2.92 & 5.71 & 8.63 & 33.8 \\
& 3.00 & 5.90 & 8.90 & 33.7 \\
\hline
\end{tabular}

${ }^{a}$ Ten-microgram samples of DNA isolated from L1210 cells grown in $10 \mu \mathrm{M}$ BrdUrd for 48 h were hydrolyzed for varying periods of time at $37^{\circ} \mathrm{C}$ using the enzyme mixture described under Materials and Methods, after which the hydrolysates were assayed for Thy and BrUra by the GC/MS method.

\pm 0.4 (SD). These data indicate that the extent of BrdUrd incorporation obtained with the GC/MS method is independent of sample size (in the range of $1-10 \mu \mathrm{g}$ ) and hydrolysis time (between $20 \mathrm{~min}$ and $16 \mathrm{~h}$ ).

In preliminary experiments we noted that the lot of thymidine phosphorylase on hand contained a small amount of Thy $(2.9 \mathrm{ng}$ $(0.02 \mathrm{nmol}) / 25$ units enzyme) which could significantly change the apparent extent of BrdUrd incorporation in very small samples (e.g., $<0.05 \mu \mathrm{g}$ ). All data reported here are corrected for the presence of this exogenous Thy.

\section{Comparison with Other Methods}

In previous studies the most common methods for determining the extent of BrdUrd incorporation have been $\mathrm{CsCl}$ gradient sedimentation $(10,11)$ or specific activity calculation following incorporation of radiolabeled BrdUrd $(4,12)$. In order to compare these techniques with the one presented here we prepared DNA samples from V79 cells exposed to various concentrations of $\left[{ }^{3} \mathrm{H}\right] \mathrm{BrdU}$ rd and then determined the extent of BrdUrd substitution by each of the three methods. Values for incorporation based on specific activity are given in Table 1 . Results found by the GC/MS method are shown in
Table 3, and data derived from $\mathrm{CsCl}$ gradients are given in Table 4. A summary of all of these data appears in Fig. 1.

As expected, each method reveals an apparent increase in incorporation with increasing drug concentration. We also observe consistent differences among the techniques, as within each group the value obtained by $\mathrm{GC} / \mathrm{MS}$ is lower than those obtained by $\mathrm{CsCl}$ gradients and higher than those seen using specific activity. Since each of these methods is prone to experimental error, none can be considered to be a standard. It is therefore difficult to make an assessment of the absolute accuracy of any of them. However, an examination of the details of each method

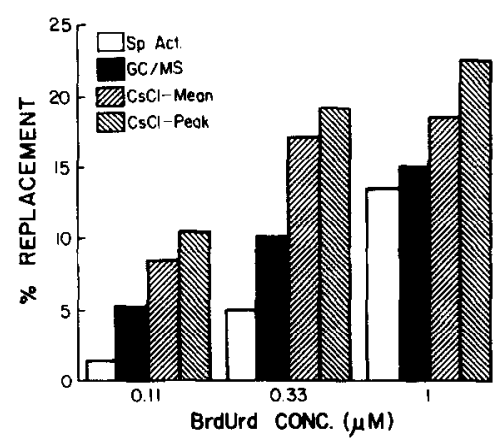

FIG. 1. Comparison of percentage replacement of Thy by BrUra, as determined by three independent methods. Data shown are a composite of results given in Tables 1 . 3 , and 4 . 
TABLE 3

ANALYSIS OF BrdUrd INCORPORATION BY GC/MS ${ }^{a}$

\begin{tabular}{cccccc}
\hline $\begin{array}{c}\text { BrUra concn. } \\
(\mu \mathrm{M})\end{array}$ & $\begin{array}{c}\text { Sample size } \\
(\mu \mathrm{g})\end{array}$ & $\begin{array}{c}\text { nmol BrUra } \\
\text { recovered }\end{array}$ & $\begin{array}{c}\text { nmol Thy } \\
\text { recovered }\end{array}$ & $\begin{array}{c}\text { Total nmol } \\
\text { recovered }\end{array}$ & $\begin{array}{c}\text { \% Replacement of } \\
\text { Thy by BrUra }\end{array}$ \\
\hline \multirow{2}{*}{0.11} & 1 & 0.037 & 0.606 & 0.643 & 5.7 \\
& & 0.029 & 0.559 & 0.588 & 4.9 \\
0.33 & 1 & 0.061 & 0.548 & 0.609 & 9.9 \\
& & 0.062 & 0.529 & 0.591 & 10.5 \\
0.33 & 10 & 0.500 & 4.49 & 4.99 & 10.0 \\
& & 0.481 & 4.23 & 4.71 & 10.2 \\
1.0 & 1 & 0.093 & 0.532 & 0.625 & 14.8 \\
& 1 & 0.104 & 0.570 & 0.674 & 15.4 \\
\hline
\end{tabular}

${ }^{a}$ Portions of the DNA samples used to produce the data shown in Table 1 were separately hydrolyzed and analyzed by $\mathrm{GC} / \mathrm{MS}$ as described in the text.

and the assumptions used in calculating incorporation values in each case suggests that the specific activity and GC/MS data may be more representative of actual incorporation than $\mathrm{CsCl}$ gradient data.

Values for incorporation based on specific activity calculations depend on experimental determination of radioactivity incorporated as BrUra, amount of DNA analyzed (or, more directly, the amount of Thy in the sample), and the specific activity of the incorporated BrUra. Data in Table 1 show that our hydrolysis procedure releases both Thy and BrUra with the same high efficiency and that greater than $95 \%$ of ${ }^{3} \mathrm{H}$ coelutes with BrUra. The hydrolysis procedure is therefore un-

TABLE 4

ANALYSIS OF BrdUrd INCORPORATION BY CsCI GRADIENT SEDIMENTATION ${ }^{a}$

\begin{tabular}{|c|c|c|c|c|c|c|c|c|}
\hline \multirow{2}{*}{$\begin{array}{l}\text { BrdUrd } \\
\text { concn. } \\
(\mu \mathrm{M})\end{array}$} & \multicolumn{2}{|c|}{${ }^{3} \mathrm{H}$} & \multicolumn{2}{|c|}{${ }^{14} \mathrm{C}$} & \multicolumn{2}{|c|}{$\%$ Replacement } & \multicolumn{2}{|c|}{$\approx$ Replacement } \\
\hline & $\begin{array}{l}\text { Peak } \\
\text { frac. }\end{array}$ & $\begin{array}{l}\text { Mean } \\
\text { frac. }\end{array}$ & $\begin{array}{l}\text { Peak } \\
\text { frac. }\end{array}$ & $\begin{array}{l}\text { Mean } \\
\text { frac. }\end{array}$ & $\begin{array}{c}\text { Using } \\
\text { peak frac. }\end{array}$ & $\begin{array}{c}\text { Group } \\
\text { mean }\end{array}$ & $\begin{array}{c}\text { Using } \\
\text { mean frac. }\end{array}$ & $\begin{array}{c}\text { Group } \\
\text { mean }\end{array}$ \\
\hline \multirow[t]{3}{*}{0.11} & 19 & 19.62 & 23 & 22.8 & 10.0 & \multirow[t]{3}{*}{10.5} & 7.7 & \multirow[t]{3}{*}{8.5} \\
\hline & 18 & 19.15 & 22 & 22.47 & 10.0 & & 8.8 & \\
\hline & 18 & 19.10 & 24 & 23.12 & 11.6 & & 8.9 & \\
\hline \multirow[t]{3}{*}{0.33} & 11 & 11.61 & 16 & 16.99 & 17.9 & \multirow[t]{3}{*}{19.2} & 18.7 & \multirow[t]{3}{*}{17.1} \\
\hline & 11 & 12.46 & 18 & 18.00 & 21.5 & & 16.4 & \\
\hline & 13 & 13.09 & 19 & 18.73 & 18.1 & & 16.3 & \\
\hline \multirow[t]{3}{*}{1.0} & 12 & 12.50 & 21 & 20.14 & 25.0 & \multirow[t]{3}{*}{22.6} & 20.5 & \multirow[t]{3}{*}{18.6} \\
\hline & 11 & 11.18 & 19 & 18.15 & 21.9 & & 18.5 & \\
\hline & 8 & 8.69 & 17 & 16.13 & 21.0 & & 16.8 & \\
\hline
\end{tabular}

\footnotetext{
${ }^{a}$ One-microgram aliquots of V79 DNA containing [ $\left.{ }^{3} \mathrm{H}\right] \mathrm{BrdUrd}$ (same preparations as in Tables 1 and 3 ) were combined with control DNA containing $\left[{ }^{14} \mathrm{C}\right] \mathrm{dTh}$ and sedimented to equilibrium in $\mathrm{CsCl}$ gradients. Tubes were punctured from the bottom and fractions were collected and assayed for radioactivity by liquid scintillation counting. Corrections for background and spillover were based on standards prepared similarly to these samples.
} 
likely to be a major source of error in either the specific radioactivity or the GC/MS calculations. Determination of Thy recovered from each HPLC injection is characterized by a coefficient of variation of $6.3 \%$ (data not shown). The radiopurity of our $\left[{ }^{3} \mathrm{H}\right]$ BrdUrd was determined by reverse-phase HPLC analysis, by coinjection of a known amount of that compound along with unlabeled BrdUrd and BrUra as carriers. All of the injected radioactivity was recovered in fractions collected for 35 min postinjection, with 96.5\% of the ${ }^{3} \mathrm{H}$ cpm eluting with BrdUrd and the remaining $3.5 \%$ eluting with BrUra. Overall, there is no obvious source of either random or systematic error greater than those ordinarily associated with HPLC analysis or scintillation counting.

In examining the sources of error associated with the GC/MS procedure, we can divide this assay into two sections: (i) DNA hydrolysis and (ii) extraction and GC/MS quantitation of released bases. Since the hydrolysis procedures for the GC/MS method and the specific activity method are identical, this portion of the assay cannot account for any observed differences between the two techniques. We have previously characterized the second half of the analytical procedure in detail and found that the coefficient of variation for determination of either BrUra or Thy is less than or equal to $10.2 \%(7)$.

Assessment of BrdUrd by $\mathrm{CsCl}$ gradient sedimentation is based on the assumptions that the change in partial specific volume of DNA caused by replacement of Thy by BrUra is negligible and that the position of the peak of radioactivity in a gradient containing DNA labeled with $\left[{ }^{3} \mathrm{H}\right] \mathrm{BrdU}$ rd is representative of the mean density of that DNA sample. While we have no reason to believe that BrdUrd incorporation causes a major alteration in DNA partial specific volume, the skewed nature of the distribution of BrdUrd-associated radioactivity (as illustrated in Fig. 2) makes the second assumption unlikely. Such asymmetrical distributions have been reported previously and were

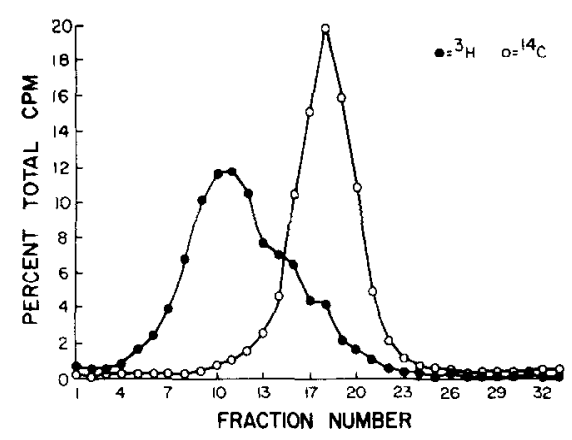

F1G. 2. Representative data are shown from an experiment in which BrdUrd replacement was assayed by $\mathrm{CsCl}$ gradient sedimentation. In this example DNA was isolated from V79 cells grown in either $0.33 \mu \mathrm{M}$ $\left[{ }^{3} \mathrm{H}\right] \mathrm{BrdUrd}$ or $\left[{ }^{14} \mathrm{C}\right] \mathrm{dThd}$ and sedimented as described in the text. The density of each odd-numbered tube was determined refractometrically (not shown).

interpreted to reflect heterogeneity in the densities of the DNA molecules under study (10). For this reason we calculated the apparent extent of BrdUrd substitution based on DNA densities corresponding to either the peak or the mean of the ${ }^{3} \mathrm{H}$ distributions in each gradient (Table 4). In all cases the valuc derived from the mean of the radioactivity distribution is lower than that derived from the peak. This difference is only significant $(P<0.05)$ in the $0.11 \mu \mathrm{M}$ group, however, and in each group the values calculated from distribution means are still higher than results obtained using the other two methods (Fig. 1).

A more important source of error is probably that, when the density label and the radioactivity label are in the same molecule, density profiles of heterogeneous DNA populations are necessarily skewed toward higher densities, as shown in Fig. 3. In this example a hypothetical population of DNA molecules is defined in which half are hybrids containing one unsubstituted strand and one $50 \%$ substituted strand $(25 \%$ substitution overall), while in the other half all strands are $50 \%$ substituted. The average percentage substitution in the total population is therefore $37.5 \%$. Since the more densely labeled molecules also contain twice as much radioactivity per unit DNA, they will form a 


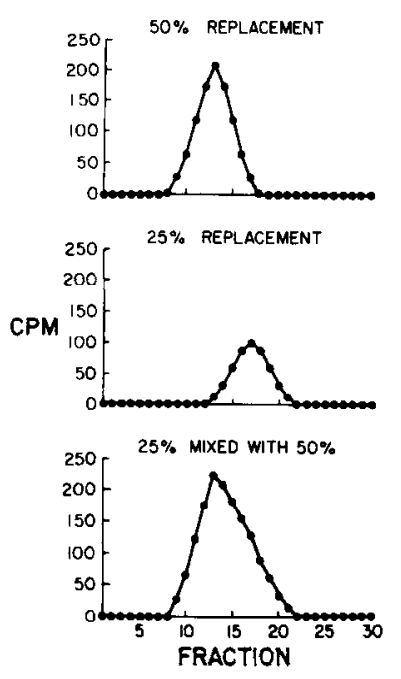

Fig. 3. Hypothetical gradient profiles are shown for DNA samples containing 25 or $50 \%$ replacement of Thy by $\left[{ }^{3} \mathrm{H}\right] \mathrm{BrUra}$, or a mixture of equal amounts of each type of DNA. A normal distribution was assumed for construction of the upper two curves.

peak with twice the height of the less densely labeled molecules, even though both types are present in equal abundance. Estimation of incorporation by using the peak of radioactivity would therefore lead to a value of $50 \%$ in this example. Even using the mean of the radioactivity peak, molecules containing higher degrees of substitution would be disproportionately weighted and the estimated value would still exceed the true value of BrdUrd incorporation. Furthermore, pieces of DNA within the subject population which were not replicated in the presence of BrdUrd would be ignored and therefore contribute to a still greater overestimation of the average extent of BrdUrd incorporation. The same analysis would apply if the two subpopulations of DNA were each substituted on both strands, but to different degrees, as could occur if BrdUrd is significantly depleted from the medium during incubation (13).

In addition to the above-mentioned differences in precision and accuracy, the three methods also possess widely varying degrees of sensitivity. For the GC/MS and specific activity techniques, the limit of detection in terms of percentage replacement depends on the size of the sample used. Assuming that 10 $\mu \mathrm{g}$ DNA is analyzed, the lowest extent of replacement detectable by GC/MS analysis would be about $0.1 \%$. This figure is based on the minimum detectable quantity of BrUra being $1.3 \mathrm{ng}$, or $0.007 \mathrm{nmol}$ (7).

The sensitivity of analysis by detection of incorporated radiolabeled BrdUrd depends on the specific activity of the material administered. In our studies, with a specific activity of $188 \mathrm{mCi} / \mathrm{mmol}$, the minimum amount of $\left[{ }^{3} \mathrm{H}\right] \mathrm{BrdU}$ rd which would be detectable above background is $0.0006 \mathrm{nmol}$. Using $10 \mu \mathrm{g}$ of DNA this translates to $0.01 \%$ replacement. Higher specific activities would give proportionally lower limits of detection in this system.

The minimum level of replacement detectable by the buoyant density approach is more difficult to determine. This parameter is not related to sample size, but rather to the precision with which differences in the gradient profiles of control and experimental DNA samples can be measured. Under the conditions used here, $0.1 \%$ replacement would be reflected by a change in density corresponding to 0.03 gradient fractions. We therefore estimate that the sensitivity limit of this method is on the order of $1 \%$ or higher.

Approaches other than those characterized here are available for analysis of halopyrimidine incorporation. For example, although we used HPLC analysis for determination of only Thy content of DNA hydrolysates, such a procedure may also be used to measure incorporated BrUra. The minimum amount of BrUra which could be detected in such samples was about $20 \mathrm{ng}$ (data not shown), equivalent to $1 \%$ replacement in a $10 \mu \mathrm{g}$ DNA sample. Also, a method involving ${ }^{32} \mathbf{P}$ postlabeling of BrdUMP derived from DNA has been reported (14). This procedure is reported to require $0.3 \mu \mathrm{g}$ of DNA, although the minimum detectable extent of replacement was not stated. The postlabeling method requires an amount of sample preparation (DNA extraction and hydrolysis) similar to that of the GC/MS procedure and has 
the advantage of employing a more commonly available analytical instrument, i.e., an HPLC. On the other hand, the run time per sample is approximately $100 \mathrm{~min}$ with the postlabeling technique, as compared to $10 \mathrm{~min}$ in the GC/MS analysis.

The preparation of monoclonal antibodies directed against incorporated BrdUrd (15) has provided the basis for a series of flow cytometric studies in which this reagent has been shown to be useful in detecting BrdUrd in DNA (e.g., (16)). Using this approach one may monitor the presence of incorporated BrdUrd in individual members of a complex population, information which is of considerable value and which is not available by other means. Evidence that indicates that the binding of such antibodies is proportional to the extent of BrdUrd replacement of $\mathrm{dThd}$ in DNA has becn presentcd (17), although this study did not describe the absolute quantitation of such replacement.

In addition to sensitivity, accuracy, and precision, other factors affect the choice of a method for analysis of BrdUrd incorporation. For example, while the specific radioactivity approach is the most sensitive of the three discussed here, its use in clinical studies would be expensive, requiring the use of large quantities of radiolabeled BrdUrd for long-term infusion studies, and would entail the unnecessary administration of radioactivity to the patient. Use of the GC/MS method would avoid these problems and would still permit analysis of very small tissue samples. Measurement of $1 \%$ replacement, which approximates the minimum required for detectable sensitization (5), would require a $1-\mu \mathrm{g}$ DNA sample, equivalent to $10^{5}$ cells or $0.1 \mathrm{mg}$ of tissue. Such a sample could easily be obtained by needle biopsy.

In summary, we have presented a new method for measuring the substitution of BrdUrd into DNA, in which incorporated Thy and BrUra are released by enzymatic hydrolysis and then quantitated by GC/MS analysis. The hydrolysis procedure has been shown to be essentially complete within 40 min and to be adequate for processing 1-10 $\mu \mathrm{g}$ DNA/sample. In addition, this method will be modified to accommodate analysis of incorporated IdUrd, as well as BrdUrd, either individually or in the same sample. The relative convenience and enhanced sensitivity of this method will permit analysis of halopyrimidine incorporation in multiple specimens containing small numbers of cells (approximately $1-2 \times 10^{5}$ ) and should be cspccially valuable in clinical studies on radiosensitization of tumors by BrdUrd or IdUrd.

\section{REFERENCES}

1. Goz, B. (1978) Pharmacol. Rev. 29, 249-272.

2. Djordjevic, B., and Szybalski, W. (1960) J. Exp. Med. 112, 509-529.

3. Erikson, R. L., and Szybalski, W. (1963) Radiat. Res. 20, 252-262.

4. Dewey, W. C., and Humphrey, R. M. (1965) Ra diat. Res. 26, 538-553.

5. Thomas, G. H., Maloney, M. A.. and Cleaver, J. E. (1982) Radiat. Res. 91, 145-154.

6. Kinsella, T. J., Mitchell, J. B., Russo, A., Morstyn, G., and Glatstein, E. (1984) Int. J. Radiat. Oncol Biol. Phys. 10, 1399-1406.

7. Stetson, P. L., Maybaum, J., Shukla, U. A., and Ensminger, W. D. (1986) J. Chromatogr. 375, 1-9.

8. Schildkraut, C. L., Marmur, J., and Doty, P. (1962) J. Mol. Biol. 4, 430-443.

9. Luk, D. C., and Bick. M. D. (1977) Anal Biochem 77, 346-349.

10. Brown, J. M., Goffinet, D. R., Cleaver, J. E., and Kallman, R. F. (1971) J. Natl. Cancer Inst. 47, 75-89.

11. Labrecque, R., and Thirion. J. P. (1976) J. Cell Physiol. 90, 321-328.

12. Cheong, L., Rich, M. A., and Eidinoff, M. L. (1960) J. Biol. Chem. 235, 1441-1447.

13. Wolff, S., and Fijtman, N. (1980) Mutat. Res. 80, 133-140.

14. Bodell, W. J., and Rasmussen, J. (1984) Anal. Biochem. 142, 525-528.

15. Gratzner, H. G. (1982) Science 218, 474-475.

16. Mayall, B. H. (Ed.) (1985) Cytometry 6, 499-662.

17. Dolbeare, F., Gratzner, H.. Pallavicini, M. G., and Gray, J. W. (1983) Proc. Natl. Acad. Sci. 80, 5573-5577. 